\title{
Aspek Tindak Pidana Korupsi Pada Perizinan Pembalakan Liar
}

\author{
M. Teguh Heriyanto ${ }^{1}$, \\ Universitas Trunojoyo Madura \\ heriyantoteguh382@gmail.com \\ Wartiningsih $^{2}$ \\ Universitas Trunojoyo Madura
}

\begin{abstract}
ABSTRAK
Seiring dengan perkembangan zaman, hutan mengalami banyak perubahan terhadap fungsi dan tujuannya. Hal tersebut tak lepas dari tujuan hutan sendiri, yaitu selain untuk mencegah terjadinya bencana-bencana alam juga dapat dimanfaatkan sumber daya alamnya. Dalam memanfaatkan hutan terkadang manusia memanfaatkannya tidak sesuai dengan peraturan perundang-undangan, salah satunya yang sering terjadi adalah illegal logging. Tindak pidana Illegal logging merupakan perbuatan menebang pohon secara liar atau secara tidak sah di kawasan hutan. Illegal logging juga menimbulkan kerugian bagi negara, kerugian keuangan negara tersebut berasal dari kayu yang ada di hutan. Adanya kerugian negara yang timbul akibat dari tindak pidana illegal logging ini kemudian dikaitkan dengan kerugian keuangan negara yang berasal dari tindak pidana korupsi. Dalam penulisan ini akan membahas secara mendalam mengenai apakah tindak pidana illegal logging dapat dikategorikan sebagai tindak pidana korupsi mengingat adaya kerugian keuangan negara yang ditimbulkan dari illegal logging. Penelitian ini menggunakan jenis penelitian hukum normatif, yaitu dengan menggunakan metode pendekatan perundang-undangan (statue approach). Sedangkan untuk bahan hukum yang digunakan dalam penelitian ini adalah menggunakan bahan hukum primer dan bahan hukum sekunder. Setelah dilakukan penelitian ini, tindak pidana illegal logging dapat dikategorikan sebagai tindak pidana korupsi apabila terdapat unsur suap-menyuap yang ada di dalamnya. Namun, apabila pada tindak pidana illegal logging tidak ditemukan adanya suap-menyuap atau korupsi maka untuk penegakan hukumnya menggunakan Undang-undang Kehutanan.
\end{abstract}

Kalimat kunci: Illegal Logging, Tindak Pidana Korupsi, Kualifikasi Tindak Pidana

\section{ABSTRACT}

Along with the times, the forests have undergone many changes in their function and purpose. This cannot be separated from the purpose of the forest itself, namely that in addition to preventing natural disasters, natural resources can also be utilized. In utilizing the forest, sometimes humans use it not in accordance with statutory regulations, one of which is illegal logging. Illegal logging is an act of cutting down trees illegally or illegally in a forest area. Illegal logging also causes losses to the state, the state's financial losses come from timber in the forest. The state losses arising from illegal logging crimes are then linked to state financial losses resulting from corruption. In this paper, we will discuss in depth whether illegal logging can be categorized as a criminal act of corruption, considering that there are state financial losses arising from illegal logging. This study uses a type of normative legal research, namely by using the statutory approach method (statue approach). Meanwhile, the legal materials used in this research are primary and secondary legal materials. After this research was carried out, the criminal act of illegal logging could be categorized as a criminal act of corruption if there was an element of bribery in it. However, if the illegal logging crime is not found bribery or corruption, then for law enforcement, use the Forestry Law.

Keywords : Illegal Logging, Corruption, Qualification of Crime 


\section{PENDAHULUAN}

Hutan merupakan satu kesatuan ekosistem yang mana memiliki sumber daya alam, memiliki berbagai macam pepohonan dan berbagai macam tumbuhan dalam satu komunitas alam yang dalam hal ini tidak bisa untuk dipisahkan satu dengan yang lain. ${ }^{1}$ Selain itu hutan memiliki berbagai macam sumber daya alam hayati yang sangat banyak dan meilimpah, seperti hutan di pulau Jawa, Kalimantan, Sumatera, Papua dan lain sebagainya. Dalam berkehidupan manusia hutan mempunyai berbagai macam sumber daya alam yaitu salah satunya adalah sumber daya alam hayati dan juga memiliki berbagai macam ekosistem yang didup di dalamnya, yang mana hal tersebut memiliki peran yang penting bagi bangsa Indonesia. ${ }^{2}$ Dengan adanya hal tersebut menjadikan hutan sebagai salah satu sumber kekayaan Negara.

Keberadaaan hutan dinilai memiliki peranan penting bagi kehidupan, hal itu dikarenakan hutan mempunyai fungsi sebagai penampung karbon dioksida dan menghasilkan oksigen, serta dapat memberikan pencegahan timbulnya

\begin{tabular}{lllr}
\hline 1 Lihat ketentuan & umum & Undang- \\
undang Nomor & 18 & Tahun & 2013 \\
tentang Pencegahan & dan & Pemberantasan \\
Perusakan Hutan & & &
\end{tabular}

2 Abdullah Marlang dan Rina Maryana, Hukum Konservasi Sumber Daya Alam Hayati dan Ekosistemnya, (Jakarta: Penerbit Mitra Wacana Media, 2015), hlm. 7. pemanasan global. Hutan juga memiliki keanekaragaman flora dan fauna yang ada di dalamnya. Dengan adanya flora dan fauna tersebut dapat mendukung terciptanya ekosistem yang kompleks, sehingga dapat bermanfaat bagi lingkungan sekitarnya. Selain itu hutan juga sebagai salah satu modal untuk dijadikan sarana pembangunan secara nasional yang mempunyai manfaat secara konkrit bagi penghidupan rakyat Indonesia. 3

Adanya kekayaan alam yang melimpah di hutan menjadikan hutan sebagai salah satu sumber kekayaan, tak jarang terdapat oknumoknum yang menyalahgunakan hutan untuk mencari kekayaan secara illegal, seperti pembakaran hutan, illegal logging atau penebangan liar, berburu flora fauna secara illegal dan lain sebagainya. Salah satu permasalahan dalam bidang hutan yang memberikan dampak yang besar adalah illegal logging atau penebangan kayu secara illegal, dampak yang ditimbulkannya adalah hutan menjadi gundul dan dapat merusak ekosistem yang ada di hutan.

Secara normatif pengaturan terkait dengan Illegal logging atau penebangan kayu ilegal terdapat pada Undang-undang Nomor Nomor 18 Tahun 2013 tentang Pencegahan dan Pemberantasan Perusakan Hutan. Penebangan kayu secara ilegal atau biasa disebut Illegal logging di kawasan hutan

${ }^{3}$ La Taati, Analisis Komposisi dan Potensi Hutan Produksi di Wilayah Kesatuan Pengelolaan Hutan (KPH), Tadulako: e-jurnal Katalogis, Volume 3 Nomor 11, 2015, hlm 203. 
milik Negara merupakan suatu tindakan illegal yang memanfaatkan hasil kekayaan sumber daya alam hayati. Istilah illegal logging atau penebangan pohon secara illegal dalam istilah Undang-undang disebut dengan pembalakan liar. Pembalakan liar adalah berbagai macam kegiatan yang memanfaatkan hasil kayu yang ada di hutan secara tidak sah dan dilakukan dengan terorganisasi. ${ }^{4}$ Sumber daya alam hayati yang sangat beragam di Negara Indonesia merupakan sebuah keuntungan bagi Negara Indonesia. Akan tetapi tidak banyak dari warga Negara Indonesia memanfaatkan sumber daya alam hayati untuk kepentingan pribadi secara ilegal.

Illegal logging atau penebangan liar merupakan suatu perbuatan yang bertentangan dengan peraturan perundang-undangan yang berlaku di Indonesia. Perbuatan penebangan liar merupakan suatu tindakan yang dapat merusak ekosistem lingkungan sekitar. Di Indonesia sendiri masih maraknya illegal logging, hal ini dikarenakan Indonesia memiliki wilayah hutan yang sangat luas selain itu banyak terjadinya suapmenyuap terkait dengan perizinan pada pejabat kehutanan. Padahal, pejabat kehutanan sendiri harus menjalankan fungsi pemerintahan dalam sistem

4 Lihat ketentuan umum Undang-undang Nomor 18 Tahun 2013 tentang Pencegahan dan Pemberantasan Perusakan Hutan pengurusan hutan secara terpadu. 5 Kelemahan inilah menjadikan masih banyaknya tindak pidana yang terjadi dalam pada bidang kehutanan.

Pasal 12 dan Pasal 82 Undang-undang Nomor 18 Tahun 2013 tentang Pencegahan dan Pemberantasan Perusakan Hutan menjelaskan bahwa unsur yang terdapat pada tindak pidana illegal logging adalah adanya suatu perbuatan yang dilarang yaitu mengangkut kayu, melakukan penebangan kayu, melakukan pengolahan, jual-beli kayu, yang dapat merusak hutan, dan perbuatan tersebut dilarang di Indonesia karena bertentangan dengan peraturan perundangundangan atau aturan hukum yang ada di Indonesia. 6

Penguasaan atas pengelolaan hutan merupakan tugas dan wewenang dari pemerintah atau pemerintah daerah yang dikelola oleh Kesatuan Pengelolaan Hutan $(\mathrm{KPH})$, jadi penguasaan sumber daya hutan merupakan penguasaan milik Negara. Semua kebijakan terkait dengan pengelolaan hutan merupakan kebijakan yang dikeluarkan oleh Negara yang mana kebijakan tersebut diwakili atau melalui Menteri Lingkungan Hidup dan Kehutanan. Dalam tindak pidana

5 Wartiningsih, Pidana Kehutanan Keterlibatan dan Pertanggungjawaban Penyelenggara Kebijakan Kehutanan, (Malang: Setara Press, 2014), hlm. 30.

6 Anis Mashdurohatun dan Bambang Tri Bawono, Penegakan Hukum Pidana Di Bidang Illegal Logging Bagi Kelestarian Lingkungan Hidup dan Upaya Penanggulangannya, Jurnal Hukum Vol XXVI, No 2. 2011. Hlm 593. 
illegal logging juga terdapat kerugian keuangan Negara, kerugian Negara yang dimaksudkan dalam hal ini adalah kayu atas perbuatan illegal logging. Akan tetapi unsur kerugian keuangan Negara tidak tercantum dalam unsur Pasal 12 Undang-undang Nomor 18 Tahun 2013 tentang Pencegahan dan Pemberantasan Perusakan Hutan yang merupakan larangan dari pembalakan liar.

Sedangkan dalam penjelasan Undangundang Nomor 31 Tahun 1999 tentang Pemberantasan Tindak Pidana Korupsi menjelaskan bahwa unsur frasa merugikan sama artinya dengan berkurang atau menjadi rugi. Sehingga yang dimaksudkan dengan unsur "merugikan keuangan Negara" memiliki persamaan arti dengan berkurangnya keuangan Negara atau menjadi ruginya keuangan negara. ${ }^{7}$ Sebagai contoh dalam kasus Illegal Logging, kerugian Negara yang dimaksudkan tidak berbentuk uang tetapi kerugian Negara yang timbul dari illegal logging adalah kayu yang ada di hutan.

Hutan merupakan kawasan milik Negara dan dikelola oleh Negara melalui Kesatuan Pengelolaan Hutan (KPH) dan untuk perizinan sendiri merupakan wewenang dari Dinas Lingkungan Hidup dan Kehutanan. Dengan demikian konsep

7 R. Wiyono, Pembahasan Undang-undang Pemberantasan Tindak Pidana Korupsi, (Jakarta: Sinar Grafika, 2013), hlm 41. dan unsur dalam illegal logging dan tindak pidana korupsi sekilas serupa akan tetapi berbeda dalam perbuatan yang dilakukan. Sehingga dengan latar belakang tersebut akan menimbulkan suatu permasalahan yaitu Illegal logging dapat dikualifikasikan sebagai tindak pidana korupsi. Berdasarkan permasalahan maka penulis memiliki ketertarikan utuk meninjau lebih dalam tentang Illegal Logging yang ditinjau dari Tindak Pidana Korupsi.

Berdasarkan permasalahan maka penulis memiliki ketertarikan utuk meninjau lebih dalam tentang Illegal Logging yang ditinjau dari Tindak Pidana Korupsi. Adapun rumusan masalah yang diangkat adalah apakah tindak pidana illegal logging dapat dikategorikan sebagai tindak pidana korupsi?

\section{METODE PENELITIAN}

Penelitian normatif dengan menggunakan pertimbangan dasar dari peraturan perundang-undangan sebagai titik dari penelitian dan dilakukan melalui studi kepustakaan untuk mengambil bahan penelitian dari buku bacaan yang dapat memberikan pengetahuan serta gambaran dari isu hukum yang dibahas. DaIam penelitian normatif biasanya diuraikan daIam 3 (tiga) hal yaitu :
a. Penelitian Asas-asas Hukum.
b. Penelitian sistematika Hukum. 
c. PeneIitian taraf sinkronisasi Hukum 8 .

Metode Pendekatan yang digunakan daIam peneIitian ini adaIah pedekatan perundang-undangan (statute approach), daIam peneIitian normatif tentuIah harus menggunakan pendekatan perundang-undangan, karena yang akan diteIiti adaIah berbagai aturan hukum yang menjadi fokus dan merupakan tema sentraI suatu peneIitian 9 .

Adapun bahan hukum yang digunakan sebagai berikut :

\section{Bahan Hukum Primer}

a. Undang-undang Nomor 28 Tahun 1999 tentang Penyelenggara Negara yang Bersih dari Kolusi, Korupsi dan Nepotisme;

b. Undang-undang Nomor 31 Tahun 1999 tentang Pemberantasan Tindak Pidana Korupsi;

c. Undang-undang Nomor 41 Tahun 1999 tentang Kehutanan

d. Undang-undang Nomor 20 Tahun 2001 tentang Perubahan Atas Undang-undang Nomor 31 Tahun 1999 tentang Pemberantasan Tindak Pidana Korupsi;

8Zainudin AIIi, Metode Peneiitian Hukum, Jakarta, Sinar Grafika, 2019, haI.24-27

9Junaedi Efendi \& Johnny Ibrahim, Metode Peneiitian Hukum Normatif Dan Empiris, Jakarta, Kencana, 2018. haI.132 e. Undang-undang Nomor 18 Tahun 2013 tentang Pencegahan dan Pemberantasan Perusakan Hutan.

\section{Bahan Hukum Sekunder}

Adapun bahan hukum sekunder buku-buku atau teks (textbooks) yang mana buku tersebut ditulis oleh orang sudah ahli dalam bidag hukum, memiliki pengaruh dalam masyarakat (deherseende leer) dan jurnal-jurnal hukum. 10 Dalam melakukan penulisan skripsi ini menggunakan buku-buku, kamus hukum, dan juga jurnal hukum. Untuk penarikan kesimpulan, bahan hukum primer dan bahan hukum sekunder dianalisis secara kualitatif.

\section{HASIL DAN PEMBAHASAN}

1. Pelanggaran Izin dalam Pengelolaan Sumber Daya Hutan yang Mengandung Suap Dapat Dikualifikasikan sebagai Tindak Pidana.

Persoalan-persoalan yang terdapat pada pengelolaan dan pemanfaatan sumber daya hutan merupakan persoalan yang menjadi persoalan secara global. Hal tersebut dikarenakan hutan berkonteks pada lingkungan hidup, yang mana antara sumber atau penyebab dan juga akibat yang ditimbulkan tidak dapat dialokasikan secara maksimal. Pun juga

10 Johny Ibrahim, Teori \& Metodologi Penelitian Hukum Normatif, (Malang: Bayumedia, 2008), hlm. 296. 
demikian berkembangnya era globalisasi di Indonesia dapat menjadikan dampak yang sangat besar untuk kelangsungam kawasan hutan sebagai penyangga kehidupan seluruh makhluk hidup yang ada di dunia. 11 Jadi, dapat dikatakan bahwa hutan yang terdapat di Indonesia merupakan salah satu pusat keanekaragaman hayati yang ada di dunia.

Adanya kekayaan hayati yang terdapat pada wilayah hutan seharusnya menjadi perhatian yang serius bagi Pemerintah untuk menegakkan pelanggaran yang sering terjadi dikawasan hutan. Pemerintah juga harus pro aktif menjaga kawasan hutan agar terlindungi dari berbagai macam permasalahan yang mengganggu ekosistem hutan. Pada prinsipnya hutan dikuasai oleh negaara demi kepentingan pembangunan nasional dan kemakmuran rakyatnya. 12 Pada Peraturan Pemerintah Nomot 44 Tahun 2004 tentang Perencanaan Kehutanan menyebutkan bahwa perencanaan dalam membentuk wilayah pengelolaan hutan memiliki tujuan untuk mewujudkan dalam mengelola hutan secara efisien dan

11 Bambang Tri Bawono dan Anies Masdhurohatun, Ibid, hlm, 591.

12 Wartiningsih, Op. Cit, hlm 31 . lestari. 13 Pembentukan wilayah dalam mengelola hutan dilaksanakan pada tingkat provinsi, kabupaten atau kota dan unit untuk pengelolaan provinsi, kabupaten atau kota merupakan wilayah kepengurusan dari kabupaten atau kota yang mencakup aktivitas-aktivitas yaitu merencanakan pengelolaan pada kehutanan, mengelola hutan, melakukan pengembangan dan penilitian, pendidikan serta melakukan penyuluhan kehutanan selain itu juga adanya pengawasan. Unit Pengelolaan Hutan atau UPH dibentuk dengan berdasar pada ketentuan yang dikeluarkan oleh Menteri. UPH ini juga terdiri dari Kesatuan Pengelolaan Hutan Konservasi yang terdapat pada hutan konservasi (KPHK), Kesatuan Pengelolaan Hutan Lindung yang terdapat pada hutan lindung (KPHL), Kesatuan Pengelolaan Hutan Produksi yang terdapat pada hutan produksi (KPHP). KPH merupakan wilayah dalam mengelola hutan sesuai dengan fungsi-fungsi pokok dan peruntukannya, yang mana harus dikelola secara efiseien dan memberikan kelestarian bagi hutan. 14 Organisasi $\mathrm{KPH}$ ini kemudian penetapannya

13 Lihat Peraturan Pemerintah Nomor 44 Tahun 2004 tentang Perencanaan Kehutanan.

14 Lihat Ketentuan Umum Peraturan Pemerintah Nomor 6 Tahun 2007 tentang Tata Hutan dan Penyusunan Rencana Pengelolaan Hutan serta Pemanfaatan Hutan. 
dilakukan oleh Menteri khususnya yang berhubungan dengan sumber daya manusia, selain itu pihak Pemerintah juga wajib memberikan perhatian terhadap syarat-syarat seperti dengan syarat kompetensi dalam bekerja kemudian akan diterbitkan sertifikasi untuk profesi yang khususnya profesi pada bidang kehutanan atau biasa disebut dengan pengakuan yang diberikan oleh Menteri. Dalam pemanfaatan pada hutan produksi harus berdasar pada pegelolaan Kesatuan Pengelola Hutan. Dalam mengelola dan melakukan pemanfaatan hasil hutan berupa kayu wajib adanya izin IPHHK atau biasa disebut dengan surat Izin Pengelolaan Hasil Hutan Kayu, surat izin tersebut dikeluarkan oleh Bupati atau Walikota yang merupakan wilayah kewenangannya, untuk izin dari Gubernur digunakan pada hutan lintas dari kabupaten atau kota yang lokasinya merupakan kewenangannya, izin dari Menteri yang digunakan untuk memanfaatkan hasil hutan kayu yang lokasinya merupakan lintas provinsi yang mana juga wajib adanya tembusan surat ke Gubernur dan juga Kepala KPH.

Pada saat pemanfaatan hutan maka pemilik izin wajib membuat susunan rencana kerja yang digunakan untuk seluruh pekerjaan dengan jangka waktu berlakunya dari izin tersebut juga berdasarkan pada rencana pengelolaan hutan yang telah disusun oleh KPH. Perusahaan atau perorangan yang memiliki izin usaha untuk mengelola hasil hutan berupa kayu yang terdapat pada wilayah hutan kemasyarakatan hanya dapat untuk memanfaatkan hasil hutan tanaman berkayu yang merupakan hasil dari yang telah ditanamnya.

Terdapat juga pada kasus di Pengadilan Mandailing Natal dengan Putusan Nomor 52 / Pid.B / 2007/ PN. Mdl, yang mana pada putusan tersebut terdapat penyimpangan yang dilakukan oleh oknum pemohon dalam mengajukan Usulan Rencana Kerja Tahunan (URT) pengelolaan dan pemanfaatan kayu yang ada di hutan. Penyimpangan tersebut terjadi karena data yang disajikan dalam Usulan Rencana Kerja Tahunan tidak sesuai atau seperti keadaan yang ada di lapangan. Dan pada saat pembuatan laporan rekapitulasi hasil cruising pada pembukaan wilyah hutan yang ditandatangani Terdakwa atau Kepala Dinas Kehutanan tidak seperti dengan kondisi jumlah pohon yang ada di hutan. Kemudian laporan yang telah ditandatangani oleh Terdakwa diajukan kepada Bupati. Perbuatan Terdakwa yang dalam hal ini adalah Kepala Dinas Kehutanan melakukan pembiaran terhadap PT. Inanta Timber untuk menebang pohon di luar wilayah areal pada rencana kerja tahunan Dinas 
Kehutanan sejak 2001 - Januari 2006. Penebangan yang dilakukan di luar izin yang diberikan yaitu izin usaha untuk memanfaatkan hasil hutan kayu (IUPHHK) juga Terdakwa seringkali mendapatkan uang ataupun hadiah serta fasilitas-fasilitas lain. Perbuatan yang dilakukan oleh PT Inanta Timber ini merupakan perbuatan suapmenyuap dengan Kepala Dinas Kehutanan Kabupaten Mandailing Natal yang sebagaimana diatur dalam Undang-undang Tipikor.

Perbuatan suap-menyuap yang dilakukan oleh PT Inanta Timber ini kepada Kepala Dinas Kehutanan. Sedangkan perbuatan yang dilakukan oleh Kepala Dinas Kehutanan adalah melakukan pembiaran untuk menebang pohon kepada PT Inanta Timber di luar jangka waktu izin yang diberikan yaitu izin untuk melakukan pemanfaatan hasil hutan kayu (IUPHHK).

Pelanggaran izin yang terdapat dalam kasus ini terdapat unsur tindak pidana korupsi di dalamnya, yaitu tentang suap-menyuap yang terdapat dalam Pasal 5 Undang-undang Nomor 31 Tahun 1999 tentang Pemberantasan Tindak Pidana

Korupsi juncto Undang-undang

Nomor 20 Tahun 2001 tentang

Perubatan atas Undang-undang

Nomor 31 Tahun 1999 tentang

Pemberantasan Tindak Pidana
Korupsi. Selain itu juga terdapat Gratifikasi yang mana dikualifikasikan dalam Pasal 12 B Undang-undang Nomor 3131 Tahun 1999 tentang Pemberantasan Tindak Pidana Korupsi juncto Undangundang Nomor 20 Tahun 2001 tentang Perubatan atas Undang-undang Nomor 31 Tahun 1999 tentang Pemberantasan Tindak Pidana Korupsi. Selain itu terdapat kasus illegal logging yang melibatkan pejabat pada tahun 2002 yang terjadi di Gresik Jawa Timur yaitu melibatkan Kepala Dinas Kehutanan Susilo Sugiono, Kepala Sub Dinas Perlidungan Hutan dan Konservasi yang bernama Basuki.15 Dalam kasus ini Pejabat Kehutanan menerima uang sebesar 152 juta untuk menerbitkan SKSHH atau Surat Keterangan Sahnya Hasil Hutan. Dengan adanya kasus ini juga menjadikan suatu acuan bahwa terkait dengan kasus illegal logging terdapat unsur suap-menyuap kepada Pejabat Kehutanan, yang mana unsur suap-menyuap merupakan perbuatan yang sebagaimana diatur dalam Undangundang Tipikor.

Selaras dengan kasus di atas Wartiningsih membenarkan dari aspek praktik peradilan bahwa untuk tindak pidana kehutanan yang dilakukan oleh pejabat, maka diterapkan Undang-undang Tipikor apabila dapat dibuktikan adanya unsur-unsur tindak pidana korupsi atau

15 Berita Harian Media Indonesia Juni 2002. 
suap. Sedangkan untuk tindak pidana kehutanan yang dilakukan oleh pejabat, maka diterapkan Undangundang Kehutanan apabila tidak terbuktinya unsur suap atau korupsi. 16 Dengan demikian tindak pidana illegal logging yang memuat unsur korupsi maka dapat dikenakan tindak pidana yang diatur dalam Undangundang Nomor 31 Tahun 1999 tentang Pemberantasan Tindak Pidana Korupsi juncto Undang-undang Nomor 20 Tahun 2001 tentang Perubatan atas Undang-undang Nomor 31 Tahun 1999 tentang Pemberantasan Tindak Pidana Korupsi.

\section{Penyalahgunaan Wewenang dalam} Perizinan Sumber Daya Hutan

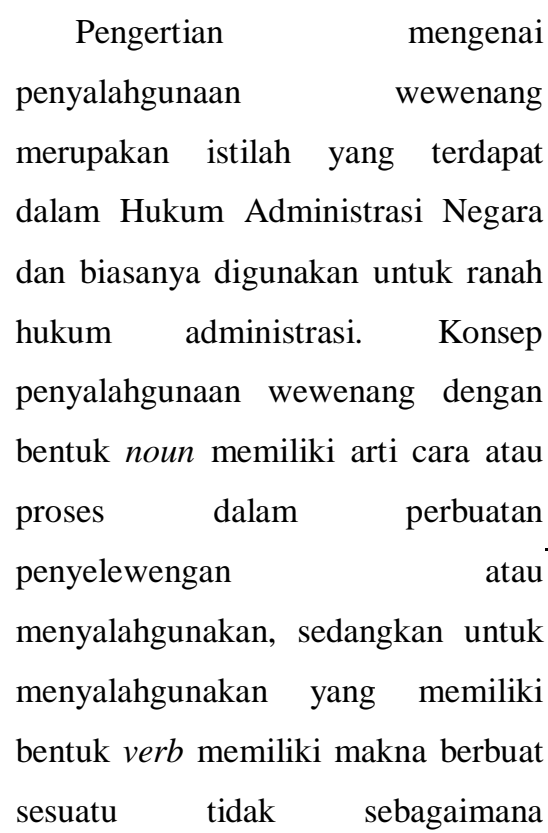

16 Wartiningsih, Op.Cit. hlm 8. semestinya, menyelewengkan. ${ }^{17}$ Konsep dalam Hukum Administrasi Negara terkait dengan penyalahgunaan wewenang selalu disejajarkan dengan konsep dari detournament de pouvoir yang terdapat pada hukum Prancis atau abuse of power/misuse of power dalam Bahasa Inggris. 18 Pertama kali istilah detournament de pouvoir muncul di Negara Prancis dan untuk dasar dari pengujian pada lembaga pada Peradilan Administrasi Negara terhadap suatu tindakan yang dilakukan oleh Pemerintah dan kemudian dianggap sebagai asas hukum dari bagian prinsip de principles generaux du droit.

Konsep detournament de pouvoir berkembang di Negara Prancis ini setelah itu memberikan pengaruh dalam melakukan penegakan hukum di berbagai negara seperti di Negara Belanda, yang mana Belanda merupakan negara jajahan dari Prancis dan dari Belanda berkembang ke Indonesia dikarenakan Indonesia merupakan jajahan dari Belanda. Untuk di Indonesia sendiri konsep penyalahgunaan wewenang menjadi dasar dalam

17 BP2B (Kemendikbud), Kamus Besar Bahasa Indonesia (KBBI), Kamus versi online/daring, kbbi.web.id/salah\%20guna.menyalahgun akan, diunduh pada Senin 16 November 2020 .

18 Philipus M. Hadjon, dkk, Hukum Administrasi dan Tindak Pidana Korupsi, Gajahmada University Press, Yogyakarta, 2012, hlm. 21-22. 
membuat gugatan untuk seseorang atau badan hukum dalam hukum perdata yang dirasa terdapat kepentingannya dirugikan atas suatu keputusan pada Lembaga Tata Usaha Negara. 19

Ketentuan yang terdapat pada hukum pidana utamanya pada tipikor terdapat istilah yang biasa disebut dengan "menyalahgunakan wewenang" yang mana terdapat dalam Pasal 3 Undang-undang Tipikor, istilah "menyalahgunakan wewenang" dalam tindak pidana korupsi dilakukan penafsiran dengan menggunakan pendekatan dari doktrin otonomi hukum pidana. ${ }^{20}$ Menurut R. Wiyono menyalahgunakan kesempatan, menyalahgunakan kewenangan, atau suatu sarana yang ada pada jabatannya atau suatu kedudukan adalah menggunakan kesempatan, kewenangan, atau sarana yang terdapat pada kedudukan atau jabatan yang dijabat olehnya atau dalam hal ini Terdakwa untuk tujuan lain dari maksud diberikannya kewenangan, kesempatan atau suatu sarana tersebut. ${ }^{21}$ R. Wiyono juga menegaskan bahwa kewenangan ada

19 Lihat Pasal 53 ayat (2) huruf b Undang-undang Nomor 5 Tahun 1986 tentang Peradilan Tata Usaha Negara.

20 Lihat Putusan Mahkamah Agung Republik Indonesia Nomor 14/Pid.sus/2012/PN.AB.

21 R. Wiyono, Op.Cit, hlm 46. jabatan dari pelaku tindak pidana korupsi adalah serangkaian yang meliputi kekuasaan atau hak pada jabatan atau kedudukan dari pelaku untuk mengambil suatu langkah yang diperlukan untuk tujuan tugas atau pekerjaanya dapat terlaksana dengan baik. ${ }^{22}$

$$
\text { Secara konsep yuridis, }
$$
penyalahgunaan wewenang yang terdapat pada Undang-undang Administrasi Pemerintahan dapat terjadi ketika pejabat pemerintahan dalam membuat suatu keputusan atau melakukan perbuatan yang telah melampaui wewenangnya, mempercampuradukan wewenang, atau melakukan tindakan sewenangwenang. 23

Penyalahgunaan wewenang ini dapat terjadi dikarenakan adanya kekuasaan (power). Penyalahgunaan wewenang dapat diartikan sebagai perbuatan yang dikerjakan oleh pemegang kekuasaan di luar dari kewenangannya, dari hal tersebut dapat berakibat adanya kerugian keuangan dari negara. ${ }^{24}$ Ketika terdapat kerugian keuangan negara yang berakibat dari penyalahgunaan kewenangan, maka kemudian hal ini menjadi konteks yang terdapat pada hukum pidana dan dapat dikategorikan melawan hukum (wederrechtelijkeheid). Ketika berbicara 22 Ibid, hlm 47.

23 Lihat Pasal 17 Undang-undang Nomor 30 Tahun 2014 tentang Administrasi Pemerintahan.

24 Nicken Sarwo Rini, Op. Cit, hlm 264. 
mengenai penyalahgunaan wewenang dalam pemanfaatan sumber daya hutan, maka dapat mengetahui terlebih dahulu wewenang siapa dalam pemanfaatan dan pengelolaan hutan. Dalam melakukan pemanfaatan dan pengelolaan sumber saya hutan diatur dalam Peraturan Pemerintah Nomor 6 Tahun 2007 tentang Tata Hutan dan Penyusunan Rencana Pengelolaan Hutan, serta Pemanfatan Hutan. Kewenangan dalam melakukan rencana dan pengelolaan hutan serta memanfaatkan hutan di wilayah perhutanan merupakan wewenang dari Pemerintah pusat maupun daerah. Pemerintah melimpahkan penyelenggaraan untuk mengelola hutan kepada BUMN dalam bidang hutan yang dalam hal ini adalah Perum Perhutani.

Perum Perhutani dapat membentuk Kesatuan Pengelolaan Hutan (KPH) dan dapat melimpahkan seluruh penyelenggaraan untuk mengelola kepada Kesatuan Pengelolaan Hutan. Selain itu terdapat juga Dinas Kehutanan yang terdapat pada setiap Kabupaten dapat mengeluarkan kebijakan perihal perizinan. 25 Dalam pemanfaatan dan pengelolaan hutan banyak kasus yang

25 Lihat Pasal 4 Peraturan Pemerintah RI Nomor 6 Tahun 2007 tentang Tata Hutan dan Penyusunan Rencana Pengelolaan Hutan, serta Pemanfaatan Hutan terjadi pada pejabat kehutanan yang mengeluarkan surat izin yang tidak semestinya dikeluarkan atau pengeluaran izin yang tidak sesuai dengan prosedur. Yang mana dalam kasus seperti ini merupakan bentuk penyalahgunaan wewenang yang termasuk kedalam jenis melampaui wewenang, dikarenakan surat izin yang dikeluarkan bertentangan dengan prosedur yang telah diatur dalam ketentuan peraturan perundang-undangan. Seperti dalam contoh kasus di Kalimantan Selatan tepatnya di Kabupaten Barabai, dalam kasus ini Kepala Dinas Kehutanan Barabai yaitu Ir. Asmullah yang telah mengeluarkan dokumen SKSHH atau biasa disebut Surat Keterangan Sah Hasil Hutan. Terdakwa yang mejabat sebagai Kepala Dinas Kehutanan telah mengeluarkan SKSHH secara mendadak dan sembunyisembunyi. Pada saat pemeriksaan 4 truk yang mengangkut kayu tidak dilakukan pemeriksaan secara fisik. 26

Dalam kasus ini terdapat adanya penyalahgunaan wewenang dari Kepala Dinas Kehutanan yang memanfaatakan kedudukan atau jabatan yang ada pada dirinya yaitu mengeluarkan SKSHH atau surat keterangan sah hasil hutan yang tidak sesuai dengan prosedur yang telah ditetapkan dalam peraturan perundangundangan. Perbuatan tersebut dapat dikategorikan sebagai penyalahgunaan

26 Berita Harian Radar Banjarmasin tanggal 25 Februari 2003. 
wewenang dalam jenis melampaui wewenang yang bertindak bertentangan dengan ketentuan dari peraturan perundang-undangan.

Selain itu perbuatan dari Kepala Dinas Kehutanan tersebut dapat menimbulkan kerugian keuangan negara yang berbentuk kayu. Kayu hasil pengangkutan yang demikian dilakukan oleh oknum tersebut juga dapat dihitung dengan menggunakan metode-metode perhitungan untuk menentukan besarnya kerugian atas perbuatan tersebut. Sehingga perbuatan tersebut juga dapat dikategorikan sebagai perbuatan melawan hukum (wederrechtdelijkeheid) dalam konsep hukum pidana. 27

\section{Unsur Suap dalam Pemanfaatan Sumber Daya Hutan}

Suap-menyuapmerupakan

perbuatan dari tindak pidana yang ada dalam Undang-undang Nomor 31 Tahun 1999 tentang Pemberantasan Tindak Pidana Korupsi juncto Undang-undang Nomor 20 Tahun 2001 tentang Perubahan atas Undangundang Nomor 31 Tahun 1999 tentang Pemberantasan Tindak Pidana Korupsi. Perbuatan suap-menyuap termasuk dalam salah satu bentuk dari tindak pidana korupsi. Dalam kasus- kasus illegal logging juga terdapat kasus yang mengandung unsur suap-menyuap, salah satu contoh adalah dalam kasus yang terdapat pada Pengadilan Negeri Mandailing Natal dengan Putusan Nomor 52 / Pid.B / 2007 / PN. Mdl tertanggal 11 Juni 2008 dengan Budi Ismoyo yang sebagai seorang Terdakwa. 28 Budi Ismoyo sendiri merupakan Kepala dari Dinas Kehutanan dan Perkebunan pada wilayah hukum Kabupaten Mandailing Natal.

Terdakwa dalam hal ini menyetujui kepada PT Inanta Timber \& Trading Coy atas pengajuan Usulan pada Rencana Kerja Tahunan (URKT) yang mana pada persyaratan yang diajukan terdapat perbedaan data yang disajikan dan tidak sesuai dengan keadaan yang seharusnya yang ada di wilayah hutan tersebut. Pembuatan Rekapitulasi Laporan Hasil Cruising atau RLHC Pembukaan Wilayah Hutan dan Pembuatan Rekapitulasi Laporan Hasil Cruising (RLHC) Tebangan Tahunan yang diberi tanda tangan oleh Terdakwa isi dari laporan tersebut tidak seperti apa yang ada di lapangan, yang mana sejak 2001 tidak dilakukan timber cruising dengan intensitas maksimal, akan tetapi Terdakwa tetap mengajukannya ke Bupati untuk disahkan.

Perbuatan Terdakwa dalam hal ini melakukan pembiaran PT Inanta Tiimber

28 Lihat Putusan Nomor
52/Pid.B/2007/PN.Mdl tertanggal 11 Juni 2008. 
\& Trading Coy untuk melakukan penebangan pohon, yang mana penebangan ini mengakibatkan pohon yang tidak termasuk Rencana Kerja Tahunan ikut ditebang. Penebangan ini terjadi pada tahun 2001 sampai dengan tahun 2006, atau atau diantara tahun 2002-2005 serta penebangan yang dilakukan di luar Izin Usaha Pemanfaatan dari PT Inanta Timber \& Trading Coy. Dalam kasus ini Terdakwa diberikan hadiah, uang dan juga fasilitas-fasilitas yang antara lain adalah penginapan dan tiket untuk perjalanan pulangnya. Pada kasus dapat diketahui bahwa dalam pemanfaatan dan pengelolaan sumber daya hutan terutama pada pemanfaatan kayu di hutan memiliki persoalan-persoalan dalam mengelola dan memanfaatkan. Salah satunya adalah illegal logging atau penebangan kayu secara illegal, terdapat campur tangan dari pihapihak yang melakuka penegakan hukum yaitu adalah Pejabat pada Dinas Kehutanan.

Perbuatan tindak pidana korupsi juga terdapat dalam kasus ini untuk melancarkan perbuatan illegal logging, suap-menyuap merupakan salah satu perbuatan untuk mempermudah illegal logging. Dalam hal ini yang seharusnya Pejabat Kehutanan yang mengawasi kawasan hutan malah ikut campur dan turut serta dalam perbuatan illegal logging. Adanya turut serta Pejabat Kehutanan ini kemudian yang menjadi persoalan tambahan dalam pengelolaan sumber daya hutan. Dengan adanya turut serta pejabat kehutanan ini kemudian menjadi salah satu tindakan mempermudah terjadinya tindak pidana illegal logging. Utamanya adalah Pejabat Kehutanan yang mengeluarkan suatu perizinan seperti dalam kasus diatas adalah Kepala Dinas Kehutanan dan pejabat kehutanan lainnya.

4. Tindak Pidana Illegal Logging yang dapat Dikualifikasikan Sebagai Tindak Pidana Korupsi

1. Pengkualifikasian Tindak Pidana Illegal Logging dalam Perspektif Tindak Pidana Korupsi

Secara normatif pengaturan mengenai tindak pidana illegal logging atau dalam istilah hukum yang ada di Indonesia adalah penebangan liar atau pembalakan liar terdapat pada Pasal 12 Undangundang Nomor 18 Tahun 2013 tentang Pencegahan dan Pemberantasan Perusakan Hutan (UU P3H).

Sebelum adanya UU P3H ketentuan mengenai tindak pidana illegal logging terdapat dalam Undang-undang Nomor 41 Tahun 1999 tentang Kehutanan. Akan tetapi pada saat adanya diundangkannya 
UU P3H telah menghapus Pasal 50 dan Pasal 78 Undang-undang Kehutanan dan memberlakukan Pasal .....UU P3H. Selain itu untuk sanksi pidana bagi pelaku pada tindak pidana illegal logging atau penebangan liar terdapat pada Pasal 82 Undang-undang Pencegahan dan Pemberantasan Perusakan Hutan.

Pada kasus-kasus illegal logging juga dapat diketahui adanya unsur kerugian negara, yang mana kerugian negara yang dimaksud adalah kerugian dari kayu hutan. Kayu yang diambil pada saat perbuatan illegal logging juga dapat diperhitungkan besarnya kerugian. Dengan adanya kerugian negara yang ditimbulkan dari tindak pidana illegal logging ini kemudian dikaitkan dengan konsep kerugian keuangan negara yang ada pada tipikor. Dalam proses penegakan hukum tidak semua kasus dapat dibebankan pada Undang-undang Tipikor. Akan tetapi, apabila tindak pidana illegal logging yang memuat unsur korupsi di dalamnya maka dapat dikenakan pada tindak pidana korupsi yang dalam hal ini diatur di Undang-undang Tipikor.

\section{ANALISIS KASUS}

Dalam putusan Nomor 290K/Pid.Sus/2009, dalam perkara dengan Terdakwa Ir. Budi Ismoyo yang bekerja sebagai Kepala Dinas Kehutanan di Kabupaten Mandailing Natal. Perkara tersebut Terdakwa mensetujui usulan dari rencana kerja tahunan di Dinas Kehutanan yang diajukan oleh PT Inanta Timber \& Trading Coy, data yang disajikan pada persyaratan pengajuan tidak seperti yang ada pada kondisi di lapangan atau dalam hal ini hutan. Selain itu Pembuatan Rekapitulasi Laporan Hasil Cruising sudah dilakukan penandatanganan oleh Terdakwa ternyata isinya tidak sesuai, sejak tahun 2001 ternyata tidak pernah adanya pengecekan atau timber cruising dengan intensitas maksimal, akan tetapi hal tersebut telah diajukan oleh Kepala Dinas Kehutanan dan disahkan oleh Bupati. Perbuatan pembiaran untuk menebang kayu oleh Terdakwa kepada PT. Inanta Timber \& Trading Coy telah mengakiabatkan adanya penebnagan yang tidak sesuai, tidak sesuainya yaitu penebangan dilakukan melewati batas pada rencana kerja awal yang dilakukan semenjak tahun 2001 - 2006, serta perbuatan tersebut tidak masuk dalam Izin yang dalam hal ini adalah Izin Pemanfaatan untuk Hasil Hutan Kayu atau IUPHHK. Terdakwa juga mendapatkan hadiah dan fasilitas-faslitas seperti penginapan dan tiket pesawat untuk perjalanan pulang serta telah memperoleh uang dari PT Inanta Timber \& Trading Coy. 29

29 Lihat Putusan Nomor 290K/Pid.Sus/2009 tertanggal 28 Januari 2010. 
Kasus ini dapat diketahui bahwa terdapat perbuatan tindak pidana korupsi yang ada kaitannya dengan kasus illegal logging. Tindak pidana korupsi yang ada pada kasus ini merupakan perbuatan yang diatur dalam Pasal 5 ayat (1) yaitu suapmenyuap dan Pasal 12 yaitu gratifikasi yang ada pada Undang-undang Tipikor. Dalam kasus ini Majelis Hakim memberikan amar putusan bahwa perbuatan Terdakwa telah terbukti secara sah membantu terjadinya tindak pidana pada bidang kehutanan dan telah membantu untuk melakukan tindak pidana perusakan hutan. Selain itu terdapat kasus keterlibatan pejabat dalam kasus illegal logging di Maluku pada bulan November 2019. 30 Keterlibatan yang dimaksudkan dalam hal ini adalah Kepala Dinas Kehutanan Maluku yaitu Sadli Le, dalam kasus ini terdapat 5 (lima) orang terdakwa yang sudah menjalani proses secara hukum. Akan tetapi yang seharusnya Kepala Dinas Kehutanan juga terjerat dalam kasus ini justru tidak tersentuh secara hukum. Salah satu terdakwa juga merupakan anak buah dari Sadli Le. Perbuatan yang dilakukan oleh Kepala Dinas Kehutanan Maluku yaitu Sadli Le membiarkan, mengetahui dan terlibat

30 Siwalimanews, 18 Mei 2020, Kadishut Maluku Harus Juga Dijerat di Illegal Logging Serut, diakses dari https://siwalimanews.com/kadishutmaluku-harus-juga-dijerat-di-illegallogging-serut/, diakses pada tanggal 02 November 2020 pukul 21.03 WIB. dalam pengangkutan kayu secara illegal. Indikator adanya keterlibatan Kepala Dinas Kehutanan ini dikarenakan salah satu anak buahnya menjadi Terdakwa dalam kasus ini yaitu Frence Permahua. Keterlibatan Kepala Dinas Kehutanan ini terdapat unsur suapmenyuap atau gratifikasi yang dilakukan oleh PT Kalisan Emas yaitu Freud Riky Purimahua. Dalam kasus tersebut yang dibawa ke ranah hukum terdapat 4 (empat)orang Terdakwa, salah satu Terdakwa bernama Frence Purmahua, S.H., S.Hut yang bekerja di Dinas Kehutanan Maluku bagian Kepala Seksi Pengembangan Fasilitas Teknis di Dinas Lingkungan Hidup. Untuk kasus ini sudah diputus dengan Putusan Nomor 25 / Pid.B / LH / 2020 /PN Msh pada tanggal 18 Mei 2020.31 Terdakwa telah terbukti secara sah untuk melakukan tindak pidana dengan sengaja turut serta melakukan pembalakan liar. Pengenaan Pasal yang dikenakan oleh Majelis Hakim adalah pada Dakwaan kedua yaitu Pasal 98 UU P3H.

Perbuatan dari Frence Purmahua, S.H., S.Hut. yang dalam hal ini bekerja si Dinas Kehutanan Maluku adalah dengan mempersiapkan kelengkapan surat-menyurat seperti untuk menyiapkan atau memperlancar urusan surat keterangan sah hasil hutan (SKSHH) yang bekerjasama dengan Kepala Dinas Kehutanan yaitu Sadli Le. Sedangkan Frence Purmahua, S.H., S.Hut. merupakan anak buah dari Sadli Le. Jika dianalisis dengan

31 Lihat Putusan Nomor 25/Pid.B/LH/2020/PN Msh tertanggal 18 Mei 2020. 
menggunakan pendapat dari Prof. Jean Rivero dan Prof. Waline, maka perbuatan yang dilakukan oleh Kepala Dinas Kehutanan Maluku yaitu Sadli Le dan juga Frence Permahua termasuk dalam penyalahgunaan kewenangan yang pertama yaitu penyalahgunaan wewenang untuk melakukan perbuatan atau tindakan yang bertentangan dengan kepentingan umum dan memberikan keuntungan bagi suatu golongan, kelompok atau pribadi. 32 Perbuatan yang dilakukan oleh Kepala Dinas Kehutanan dan Frence Permahua bertujuan untuk menguntungkan pribadi yang bertentangan dengan kepentingan umum serta bertentangan dengan ketentuan peraturan perundang-undangan. Dalam kasus tersebut Frence Permahua dipidana sebagai turut serta melakukan tindak pidana illegal logging. Apabila melihat pada penyertaan yang ada dalam konsep Kitab Undang-undang Hukum Pidana yaitu sebagai berikut: 33

\section{A. Pembuat (Dader)}

\section{Pelaku/Pleger}

Biasa dikenal dengan istilah orang yang melakukan dengan sendirinya perbuatan, perbuatan ini telah memenuhi rumusan suatu delik.

2. Menyuruhlakukan/doenplege

32 Putusan MARI Nomor 977K/PID/2004, tanggal 10 Juni 2005, hlm 197-198.

33 Eddy O. S. Hiariej, Op. Cit, hlm

351.

$r$

Menyuruhlakukan merupakan seseorang yang melakukan perbuatan dengan adanya perantara dari orang lain, yang mana orang tersebut dimanfaatkan sebagai alat (alat sebagai pembuat materiil).

3. Turut serta / medepleger

Turut serta merupakan seseorang yang dengan sengaja untu turut melakukan atau turut mengerjakan suatu tindak pidana.

4. Penganjur/uitlokker

Penganjur merupakan orang yang menggerakkan orang lain supaya orang tersebut melakukan suatu tindak pidana, dengan cara menggunakan sarana yang telah ditentukan dalam Pasal 55 ayat (1) ke-2 KUHP yaitu memberikan sesuatu atau menjanjikan sesuatu, dengan menyalahgunakan martabat atau kekuasaan yang ada padanya, dengan adanya ancaman, penyesatan atau kekerasan, atau dengan memberikan kesempatan, sarana lain atau dengan keterangan.

B. Pembantu (Medeplichtge)

1) Pada saat kejadian

2) Sebelum kejahatan

Kedua perbuatan ini hanya merupakan perbuatan membantu/menunjang, tidak 
harus adanya kerjasama yang disadari dan tidak memiliki kepentingan/tujuan tersendiri. Seharusnya Frence Permahua yang mejabat di Dinas Kehutanan dan Sadli Le yang mejabat sebagai Kepala Dinas Kehutanan Maluku bukan sebagai turut serta atau membantu melakukan terjadinya tindak pidana, dikarenakan perbuatan dari Terdakwa adalah mempersiapkan dokumen kelengkapan dan menerbitkan Surat Keterangan Sahnya Hasil Hutan Kayu. Juga dalam fakta di persidangan terdapat unsur suap yang dilakukan oleh Perusahaan yaitu PT Talisan Emas kepada Kepala Dinas Kehutanan. Dikarenakan Terdakwa dipidana sebagai turut serta atau membantu melakukan tindak pidana maka juga akan bertentangan dengan prinsip yang ada pada Pasal 52 KUHP.

Prinsip yang ada pada Pasal 52 KUHP ini merupakan pemberatan yang digunakan untuk melakukan pemberatan terhadap pejabat karena melanggar suatu kewajibannya. Dengan demikian seharusnya Hakim bukan menjatuhkan pidana sebagai turut serta atau membantu melakukan tindak pidana, akan tetapi sebagai pelaku utama dikarenakan pejabat kehutanan sebagai ujung tombak dalam melakukan penegakkan hukum atas Undang-undang Pencegahan dan Pemberantasan Perusakan Hutan. logging yang melibatkan pejabat kehutanan, maka dalam menegakkan hukum di bidang kehutanan dapat menggunakan UU P3H dan juga dapat menggunakan Undang-undang Nomor 31 Tahun 1999 tentang Pemberantasan Tindak Pidana Korupsi juncto Undangundang Nomor 20 Tahun 2001 tentang Perubahan atas Undang-undang Nomor 31 Tahun 1999 tentang Pemberantasan Tindak Pidana Korupsi.

Tindak pidana korupsi dapat dikenakan pada tindak pidana illegal logging dengan syarat adanya unsur tindak pidana korupsi pada saat melakukan tindak pidana illegal logging seperti adanya suap-menyuap, gratifikasi dan perbuatan tindak pidana korupsi lainnya. Sebagaimana pendapat dari Direktur Lembaga Sosial Masyarakat WALHI beliau mengatakan bahwa sumber permasalahan dari illegal logging merupakan adanya adalah adanya tindak pidana korupsi di dalamnya, hal tersebut dapat dilihat dari adanya izin-izin dalam mengelola hutan yang mana pengelolaannya dikelola oleh Pemerintah atau Pemerintah Daerah. 34

Berdasarkan praktik penerapan Undang-undang Tipikor dan Undangundang Kehutanan pada kasus keterlibatan pejabat dalam penerbitan izin tanpa memenuhi syarat-syarat yang telah ditentukan oleh peraturan

Maraknya kasus-kasus illegal

34 IGM Nudjana, Op.Cit, hlm 125 
perundang-undangan

kehutanan,

bidang

Wartinigsih

menyimpulkan bahwa untuk tindak pidana yang dilakukan oleh pejabat pada bidang kehutanan, maka menggunakan Undang-undang Tindak

Pidana Korupsi apabila unsur korupsi atau suap-menyuap dapat dibuktikan di dalamnya. Sedangkan untuk tindak pidana yang dilakukan oleh pejabat pada bidang kehutanan, maka dapat diterapkan Undang-undang Kehutanan apabila tidak adanya unsur korupsi atau suap di dalamnya. 35 Akan tetapi tidak setuju dengan praktik yang demikian itu, karena setiap undangundang memiliki norma yang hendak dilindungi. Undang-undang Tipikor memiliki norma yang menjadi sasaran untuk dilindungi yang berbeda dengan Undang-undang Kehutanan. Meskipun demikian dalam penegakan hukum bidang kehutanan sering kali menemukan adanya penerapan Undang-undang Pemberantasan Tindak Pidana Korupsi.

Apabila tidak terbukti adanya unsur suap-menyuap atau gratifikasi di dalamnya maka akan diterapkan UU P3H yaitu Pasal 82 yang pada intinya menjelaskan larangan bagi orang perseorangan dan korporasi yang melakukan penebangan pohon hutan tidak sesuai izin, melakukan

35 Wartiningsih, Op. Cit, hlm 8. penebangan pohon tanpa izin dan melakukan penebangan pohon secara tidak sah. Selain itu juga Pasal 83 UU P3H yang pada intinya menjelaskan larangan bagi orang perorangan atau korporasi yang melakukan pemuatan, pembongkaran, pengeluaran, pengangkutan, menguasai atau memiliki hasil penebangan tanpa izin atau tidak dilengkapi surat keterangan sahnya hasil hutan atau memanfaatkan hasil hutan kayu yang patut diduga hasil dari pembalakan liar.

\section{KESIMPULAN}

Tindak pidana illegal logging dapat dikategorikan sebagai tindak pidana korupsi apabila ditemukan unsur suap atau gratifikasi. Illegal logging merupakan perbuatan melawan hukum dan merupakan tindak pidana yang diatur dalam UU $\mathrm{P} 3 \mathrm{H}$. Pembalakan liar atau penebangan pohon secara liar atau Illegal logging merupakan suatu tindakan memanfaatkan hasil hutan dengan melakukan penebangan kayu secara ilegal. Dalam tindak pidana illegal logging juga terdapat akibat yang dapat merugikan negara, yang mana kerugian negara tersebut berasal dari kayu yang dapat diperhitungkan besarannya. Adanya kerugian negara ini kemudian disandingkan dengan kerugian keuangan negara yang ada pada tindak pidana korupsi. Selain itu dalam beberapa kasus illegal logging terdapat keterlibatan pejabat kehutanan. Keterlibatan pejabat kehutanan ini terdapat pada tahap-tahap awal perizinan 
maupun pada saat akhir yaitu terbitnya surat keterangan sah hasil hutan atau SKSHH. Keterlibatan pejabat kehutanan ini kemudian diarahkan pada perbuatanperbuatan dalam ranah korupsi seperti suap - menyuap dan gratifikasi. Dalam upaya penegakan hukum pada tindak pidana illegal logging yang dilakukan oleh pejabat maka dapat diterapkan Undang-undang Pemberantasan Tindak Pidana Korupsi apabila dapat dibuktikan adanya unsur-unsur korupsi atau suap menyuap dan untuk tindak pidana illegal logging yang dilakukan oleh pejabat, maka dapat diterapkan UU P3H apabila unsur tindak pidana korupsi tidak dapat dibuktikan.

Maraknya tindak pidana illegal logging yang melibatkan pejabat kehutanan harus diberikan perhatian khusus oleh Pemerintah. Karena dalam pengelolaan dan pemanfaatan hutan, pejabat kehutanan memiliki peranan penting sebagai aparat penegak hukum. Aparat penegak hukum yang seharusnya melakukan penegakkan dalam pengawasan untuk pengelolaan dan pemanfaatan sumber daya hutan malah dapat mempermudah akses terjadinya illegal logging, salah satunya adalah dengan adanya suap-menyuap atau gratifikasi yang diberikan kepada Pejabat Kehutanan. Adanya permasalahan tersebut dapat menjadi permasalahan yang cukup serius, mengingat hutan merupakan salah satu sumber kekayaan negara. Pemerintah seharusnya memberikan pengawasan secara aktif dan menyeluruh kepada pejabat kehutanan dan menindak secara tegas apabila terdapat keterlibatan pejabat dalam kasuskasus bidang kehutanan khususnya illegal logging. Dengan upaya yang demikian, setidaknya akan dapat menurunkan banyaknya kasus keterlibatan pejabat pada kasus illegal logging dan untuk menjawab permasalahan ini.

\section{DAFTAR RUJUKAN}

Abdullah Marlang dan Rina Maryana, 2015. Hukum Konservasi Sumber Daya Alam Hayati dan Ekosistemnya, Jakarta: Mitra Wacana Media.

Andi Hamzah, 2002. Pemberantasan Korupsi ditinjau dari Hukum Pidana, Jakarta: Pusat Studi Hukum Pidana Universitas Trisakti.

Abdul Latif, 2014. Hukum Administrasi Dalam Tindak Pidana Korupsi, Jakarta: Penada Media Group.

Bahder Jihan Nasution, 2008. Metode Penelitian Ilmu Hukum, Bandung: Mandar Maju.

Bambang Sunggono, Metodologi Penelitian Hukum, Jakarta: Rajawali Press, 2010.

Johny Ibrahim, 2008. Teori \& Metodologi Penelitian Hukum Normatif, Malang: Bayumedia.

Eddy O.S. Hiariej, 2016. Prinsip-prinsip Hukum Pidana Edisi Revisi, Yogyakarta: Cahaya Atma Pusaka.

Emerson Yuntho, dkk, 2014. Penerapan Unsur Kerugian Keuangan Negara 
dalam Delik Tindak Pidana Korupsi,

Jakarta: Indonesia Corruption

Watch.

Komisi Pemberantasan Korupsi, 2006.

Memahami Untuk Membasmi: Buku

Saku Untuk Memahami Tindak

Pidana Korupsi, Komisi

Pemberantasan Tindak Pidana

Korupsi, Jakarta.

Nudjana, IGM. 2005, Korupsi \& Illegal

Logging Dalam Sistem

Desentralisasi, Pustaka Pelajar,

Yogyakarta.

Peter Mahmud Marzuki, 2011. Penelitian

Hukum, Jakarta: Kencana.

Philipus M. Hadjon, dkk, 2012. Hukum Administrasi dan Tindak Pidana Korupsi, Yogyakarta: Gajahmada University Press.

Pimpinan Pusat Ikatan Hakim Indonesia (PP IKAHI), 2016. Undang-undang Administrasi Pemerintahan dalam Upaya Pemberantasan Korupsi, Sinar Grafika, Jakarta Timur.

Ridwan HR, 2006. Hukum Administrasi Negara, Jakarta: Raja Grafindo Persada.

R. Wiyono, 2013. Pembahasan Undangundang Pemberantasan Tindak Pidana Korupsi, Jakarta: Sinar Grafika.

Salim, 1987. Kamus Indonesia Inggris, Modern English Press, Jakarta.

Suhendar, 2015. Konsep Kerugian Keuangan Negara Pendekatan Hukum Pidana, Hukum Administrasi
Negara dan Pidana Khusus Korupsi, Malang: Setara Press.

Tim Penyusun Modul Badan Diklat Kejaksaan R.I, 2019. Modul Tindak Pidana Korupsi, (Jakarta: Badan Diklat Kejaksaan R.I.

Wartiningsih, 2014. Pidana Kehutanan Keterlibatan dan Pertanggungjawaban Penyelenggara Kebijakan Kehutanan, Malang: Setara Press.

Bambang Tri Bawono dan Anies Masdhurohatun, 2011. Penegakan Hukum di Bidang Illegal Logging Bagi Kelestarian Lingkungan Hidup dan Upaya Penanggulangannya, Semarang: Jurnal hukum Vol XXVI, No. 2.

I Ketut Sundra, 2017. Pengelolaan Sumber Daya Hutan, Denpasar: Paper presented by Jurusan Biologi Fakultas Matematika dan Ilmu Pengetahuan Alam Universitas Udayana.

Muhammad Kurniawan, 2016. Penggelapan Uang dan Surat Berharga oleh Pegawai Negeri Sebagai Tindak Pidana Khusus dalam Pasal 8 Undang-undang Tindak Pidana Korupsi, Manado: Lex Crimen Vol. 5/ No. 5.

Mohammad Sahlan, 2016. Unsur Menyalahgunakan Kewenangan dalam Tindak Pidana Korupsi sebagai Kompetensi Absolut Peradilan Administrasi, Jakarta: Jurnal Hukum Ius Quia Iustum No. 2 Vol 23.

Nicken Sarwo Rini, 2018. Penyalahgunaan Kewenangan Administrasi Dalam 
Undang-undang Tindak Pidana

Korupsi, Jurnal Penelitian Hukum

De Jure.

Undang-undang Nomor 31 Tahun 1999 tentang Pemberantasan Tidak Pidana

Korupsi. (Lembaran Negara Republik Indonesia Tahun 1999 Nomor 140, Tambahan Lembaran Negara Republik Indonesia Nomor 3874)

Undang-undang Nomor 41 Tahun 1999 tentang Kehutanan. (Lembaran Negara Republik Indonesia Tahun 1999 Nomor 167, Tambahan Lembaran Negara Republik Indonesia Nomor 3888).

Undang-undang Nomor 20 Tahun 2001

tentang Perubahan atas Undangundang Nomor 31 Tahun 1999 tentang Tindak Pidana Korupsi (Lembaran Negara Republik Indonesia Tahun 2001 Nomor 134, Tambahan Lembaran Negara Republik Indonesia Nomor 4150)

Undang-undang Nomor 28 Tahun 2013 tentang Pencegahan dan Pemberantasan Kawasan Hutan. (Lembaran Negara Republik Indonesia Tahun 2013 Nomor 130, Tambahan Lembaran Negara Republik Indonesia Nomor 5432)

Undang-undang Nomor 30 Tahun 2014 tentang Administrasi Pemerintahan (Lembaran Negara Republik Indonesia Tahun 2014 Nomor 292, Tambahan Lembaran Negara
Republik Indonesia Nomor 5601)

Program Perencanaan Pembangunan Tahun

2000-2004 Bab X tentang

Pembangunan Sumber Daya Alam dan

Lingkungan Hidup.

Putusan Mahkamah Konstitusi Nomor

25/PUU-XIV/2016 tertanggal 25

Januari 2017

Putusan MARI Nomor 977K/PID/2004, tanggal 10 Juni 2005 tertanggal 10 Juni 2005.

Putusan Pengadilan Mandailing Natal Nomor 52/Pid.B/2007/PN.Mdl tertanggal 11 Juni 2008.

Putusan Mahkamah Agung Republik Indonesia Nomor 14/Pid.sus/2012/PN.AB.

Putusan Negeri Masohi Nomor 25/Pid.B/LH/2020/PN Msh tertanggal 18 Mei 2020

Badan Pengembangan dan Pembinaan Bahasa Kementerian Pendidikan dan Kebudayaan (BP2B, Kemendikbud), Kamus Besar Bahasa Indonesia (KBBI), Kamus versi online/daring, kbbi.web.id/salah\%20guna.menyalahgu nakan, diunduh pada Senin 16 November 2020

Berita Harian Media Indonesia tertanggal bulan Juni 2002.

Berita Harian Radar Banjarmasin tanggal 25 Februari 2003.

Siwalimanews, 18 Mei 2020, Kadishut Maluku Harus Juga Dijerat di Illegal Logging Serut, diakses dari https://siwalimanews.com/kadishut- 
maluku-harus-juga-dijerat-di-illegal-

logging-serut/, diakses pada tanggal

02 November 2020 pukul 21.03

WIB. 